\title{
Upaya Meningkatkan Kedisiplinan Siswa dalam Menaati Tata Tertib Melalui Layanan Penguasaan Konten dengan Teknik Modelling pada Siswa Kelas VII A SMP Negeri 19 Kota Jambi Tahun Ajaran 2015/2016
}

\author{
Arnita Liana ${ }^{1}$
}

\begin{abstract}
Abstrak: Disiplin merupakan salah satu kecakapan hidup yang sangat penting dan perlu dimiliki oleh setiap orang guna mencapai kesuksesan dalam hidupnya, tidak hanya kesuksesan dalam belajar tetapi juga kesuksesan dalam hidup bermasyarakat. Sikap disiplin menaati tata tertib meliputi tiga aspek yaitu: pemahaman tentang peraturan yang berlaku, sikap mental yang baik dan kesungguhan dalam menaati tata tertib. Fenomena di lapangan menunjukkan kondisi kedisiplinan siswa kelas VII A SMP Negeri 19 Kota Jambidalam ketiga aspek tersebut masih rendah. Permasalahan yang ingin dikaji dalam penelitian ini adalah mengetahui gambaran kedisiplinan siswa kelas VII A dalam menaati tata tertib sebelum dan setelah diberi layanan penguasaan konten dengan teknik modelling. Jenis penelitian adalah penelitian eksperimen. Populasi penelitian ini adalah semua siswa kelas VII SMP Negeri 19 Kota Jambi. Teknik sampling yang digunakan adalah Cluster Random Sampling dan kelas VII A yang menjadi sampel penelitian dengan jumlah responden 32 siswa. Metode pengumpulan data pada penelitian ini menggunakan instrumen skala kedisiplinan sebanyak 63 item. Instrument tersebut telah diujicobakan untuk digunakan dalam penelitian. Metode analisis data menggunakan deskriptif persentase dan t-test. Hasil penelitian yang diperoleh, tingkat kedisiplinan siswa sebelum mendapatkan layanan penguasaan konten tergolong dalam kategori sedang dengan persentase 66,6\% Setelah mendapatkan penguasaan konten meningkat menjadi 77,6\% dalam kategori tinggi. Dengan demikian mengalami peningkatan sebesar $11 \%$. Dari perhitungan uji $\mathrm{t}$-test diperoleh $\mathrm{t}$ hitung $=10,67>\mathrm{t}$ table $=2,04$. Hasil tersebut menunjukkan bahwa layanan penguasaan konten dengan teknik modelling dapat meningkatkan kedisiplinan siswa.
\end{abstract}

Kata Kunci: kedisiplinan dalam menaati tata tertib, layanan penguasaan konten dengan teknik modelling.

Abstract: Discipline is one of life skills that is very important and needs to be owned by everyone in order to achieve success in life, not only success in learning but also success in living in a community. Discipline adheres to the order includes three aspects, namely: understanding of the applicable regulations, good mental attitude and sincerity in obeying the rules. The phenomenon in the field shows the disciplinary conditions of class VII A SMP Negeri 19 Kota Jambid in these three aspects are still low. The problem to be examined in this study is to know the description of discipline of VII A grade students in obeying the rules before and after being given content mastery services with modeling techniques. This type of research is experimental research. The population of this study was all students of class VII SMP Negeri 19 Kota Jambi. The sampling technique used was Cluster Random Sampling and class VII A which became the study sample with the number of respondents 32 students. The method of data collection in this study used a disciplinary scale instrument of 63 items. The instrument has been tested for use in research. The method of data analysis uses descriptive percentages and t-tests. The results of the study obtained, the level of discipline of students before getting content mastery services belong to the medium category with a percentage of $66.6 \%$ after getting mastery of content increased to $77.6 \%$ in the high category. Thus an increase of $11 \%$. From the calculation of the $t$-test obtained $t$ count $=10.67>t$ table $=2.04$. These results indicate that content mastery services with modeling techniques can improve student discipline.

Keywords: discipline in obeying order, content mastery services with modeling techniques.

\section{PENDAHULUAN}

Pada saat ini Indonesia telah memasuki era pasar bebas dimana setiap orang dapat memasuki Indonesia untuk beraktifitas tanpa melihat kewarganegaraannya. Kondisi ini menuntut setiap warga negara Indonesia untuk mampu bersaing dengan warga negara lain karena tonggak kemajuan sebuah bangsa untuk bisa bersaing di pasar bebas bergantung pada mutu sumber daya manusia yang dimiliki. Oleh karena itu diperlukan berbagai macam kompetensi dan kecakapan hidup yang harus dimiliki oleh warga negara Indonesia agar mampu bersaing dengan warga negara lain. Salah satu kompetensi tersebut adalah disiplin diri.

${ }^{1}$ Sekolah Menengah Pertama Negeri (SMPN) 19 Kota Jambi 
Mengutip pernyataan dari Durkheim (1990:35) yang menyebutkan bahwa disiplin mempunyai tujuan ganda yaitu untuk mengembangkan suatu keteraturan tertentu dalam tindak-tanduk manusia dan memberikan suatu sasaran tertentu yang sekaligus juga membatasi cakrawalanya. Selain itu Rimm (2003: 47) mengungkapkan bahwa disiplin mempunyai tujuan untuk mengarahkan anak agar mereka belajar mengenai hal-hal baik yang merupakan persiapan bagi masa dewasa, saat mereka sangat bergantung pada disiplin diri. Berdasarkan dua pendapat tersebut dapat diketahui bahwa disiplin sangat penting untuk menjadikan individu lebih terarah dalam menjalani kehidupannya.

Disiplin merupakan salah satu kecakapan hidup yang sangat penting dan perlu dimiliki oleh setiap orang guna mencapai kesuksesan dalam hidupnya. Akan tetapi tidak dapat dipungkiri jika masih banyak orang yang tidak menerapkan disiplin dalam kehidupannya. Terdapat banyak alasan mengapa seseorang tidak dapat berlaku disiplin, diantaranya adalah malas, belum terbiasa dengan disiplin, dan belum mampu bersikap tegas pada diri sendiri. Oleh karena itu diperlukan adanya sebuah upaya agar seseorang dapat berlaku disiplin. Salah satu caranya adalah melalui pendidikan baik pendidikan formal maupun non formal.

SMP Negeri 19 Kota Jambi adalah salah satu sekolah menengah pertama dengan standar nasional. Mereka mempunyai kebiasaan yang berbeda-beda baik dari cara belajar, bergaul hingga dalam mematuhi peraturan yang telah ditetapkan oleh pihak sekolah. Seperti halnya di sekolah lain di SMP Negeri 19 Kota Jambi juga terdapat peraturan-peraturan yang harus ditaati oleh setiap siswa. Peraturan ini ditetapkan dengan tujuan agar para siswa berhasil dalam menuntut ilmu selama berada di SMP Negeri 19 Kota Jambi. Peraturan yang ada di sekolah ini tidak hanya berkaitan dengan hal belajar tetapi juga dalam hal beribadah dan bersosialisasi dengan orang lain. Hal ini bertujuan agar setiap siswa dapat berlaku disiplin dalam segala aspek kehidupan di sekolah pada khususnya dan aspek kehidupan di masyarakat pada umumnya.

Berdasarkan hasil pengamatan selama melaksanakan Penelitian di SMP Negeri 19 Kota Jambi peneliti menangkap fenomena banyaknya siswa yang melanggar tata tertib sekolah. Pada tata tertib sekolah terdapat poin yang menyebutkan bahwa tanda bel masuk dibunyikan pada pukul 07.00 WIB, siswa harus sudah masuk kelas kemudian berdoa bersama dengan dipandu Bapak/lbu guru. Akan tetapi peneliti menemui banyaknya siswa kelas VII A di dalam kelas yang tidak berdoa dengan khusyuk, mereka sering berbicara dengan teman- temannya atau mengerjakan PR.

Salah satu guru pembimbing di SMP Negeri 19 Kota Jambi mengemukakan bahwa seluruh siswa SMP Negeri11 memahami akan adanya peraturan-peraturan yang telah ditetapkan oleh sekolah. Akan tetapi hal tersebut masih berhenti pada tingkat pemahaman saja belum dimanifestasikan dalam sebuah tindakan. Masih terdapat banyak siswa yang tidak mematuhi peraturan yang berlaku sehingga perilaku disiplin belum tampak pada diri setiap siswa. Masalah pelanggaran tata tertib yang dilakukan oleh siswa belum diadministrasikan dengan baik karena tidak adanya petugas khusus yang menangani masalah kedisiplinan siswa. Apabila siswa telah melakukan pelanggaran tata tertib berulang kali biasanya dilimpahkan ke guru pembimbing untuk selanjutnya mendapatkan pelayanan BK.

Berdasarkan hasil studi pendahuluan yang dilakukan oleh peneliti pada saat melaksanakan Penelitian di SMP Negeri 19 Kota Jambi diperoleh data bahwa tingkat kesadaran untuk berdisiplin siswa SMP Negeri 19 Kota Jambi masih rendah. Hal ini ditunjukkan dengan masih banyaknya pelanggaranpelanggaran tata tertib yang dilakukan oleh siswa. Menurut Wijaya (1991: 18) siswa dikatakan disiplin dapat dilihat dari beberapa indikator berikut: melaksanakan tata tertib dengan baik, taat terhadap kebijakan yang berlaku, menguasai diri dan introspeksi (mempunyai sense of responsibility). Akan tetapi indikatorindikator tersebut belum ditemukan pada siswa SMP Negeri 19 Kota Jambi khususnya pada kelas VII A. Hal ini ditunjukkan dengan masih banyaknya pelanggaran-pelanggaran tata tertib yang dilakukan oleh siswa. Pelanggaran tata tertib yang sering dilakukan antara lain adalah setiap hari terdapat siswa yang datang terlambat rata- rata sebanyak 1,6\%. Selain itu jumlah siswa yang tidak masuk sekolah tanpa keterangan pada awal tahun ajaran 2015/2016 adalah sebesar 25\%.

Selain sering tidak masuk tanpa alasan juga masih ada banyak siswa yang terlambat masuk ke kelas untuk mengikuti jam pelajaran. Ketika di dalam kelas mereka tidak mengikuti pelajaran dengan baik, biasanya mengobrol sendiri atau lebih asyik menggambar ketika guru sedang menerangkan. Ketika peneliti mengajar ada $30 \%$ siswa yang selalu datang terlambat masuk ke dalam kelas, mereka sering beralasan dari kamar mandi. Ketika jam pelajaran sudah dimulai siswa tidak segera masuk kelas tapi harus disuruh dulu baru mereka masuk kelas. Sense of responsibility yang dimiliki siswa SMP Negeri 19 Kota Jambi terutama 
dalam hal belajar masih rendah. Hal ini ditunjukkan tidak teraturnya jadwal belajar siswa, mereka tidak mempunyai jadwal pribadi untuk mengatur belajar di luar jam sekolah. Peneliti mengamati dampak yang timbul karena siswa tidak mempunyai kedisiplinan dari dalam diri yaitu banyak siswa yang terkena kasus pergaulan bebas yaitu: merokok, video porno dan gaya pacaran yang berlebihan.

Terdapat banyak faktor yang mempengaruhi disiplin seseorang, menurut Tu'u (2004: 48-50) disiplin dipengaruhi oleh kesadaran diri, pengikutan dan ketaatan terhadap peraturan, alat pendidikan yang mempengaruhi perubahan perilaku, serta hukuman sebagai penyadaran. Mengacu pada teori tersebut serta fenomena yang terjadi di SMP Negeri 19 Kota Jambi dapat dikatakan bahwa permasalahan rendahnya disiplin siswa lebih dipengaruhi dari faktor kesadaran diri. Berdasarkan hal tersebut maka diperlukan adanya suatu usaha untuk menumbuhkan disiplin siswa yang didasari atas kesadaran dari masing-masing individu.

Salah satu cara yang dapat digunakan untuk meningkatkan disiplin siswa adalah dengan menggunakan layanan bimbingan dan konseling. Layanan bimbingan dan konseling merupakan sebuah bentuk layanan yang ditujukan kepada setiap individu dan bertujuan untuk memandirikan setiap individu. Salah satu layanan yang dapat digunakan untuk meningkatkan disiplin siswa adalah dengan menggunakan layanan penguasaaan konten. "Layanan penguasaaan konten merupakan layanan yang mempunyai fungsi agar seseorang dapat menguasai suatu konten tertentu untuk menambah wawasan dan pemahaman, mengarahkan penilaian sikap, menguasai cara atau kebiasaan tertentu untuk memenuhi kebutuhannya dan mengatasi masalah-masalahnya" (Prayitno, 2004: 2).

Alasan peneliti menggunakan layanan penguasaan konten untuk meningkatkan disiplin siswa karena peneliti ingin menumbuhkan disiplin yang didasari atas kesadaran diri. Permasalahan kedisiplinan yang dihadapi oleh siswa SMP Negeri 19 Kota Jambi perlu diselesaikan dengan menggunakan pendekatan yang lebih bersifat personal. Layanan penguasaan konten dapat dilakukan secara klasikal tanpa meninggalkan aspek-aspek personal individu yang butuh untuk dikembangkan. Hal ini sesuai dengan yang dikemukakan oleh Prayitno (2004: 8) bahwa: "Layanan penguasaaan konten pada umumnya diselenggarakan secara langsung (bersifat direktif) dan tatap muka dengan format klasikal, kelompok, atau individual dengan tetap memberikan sentuhan-sentuhan pada aspek-aspek kepribadian dan kemanusiaan peserta layanan (terutama aspek afektif, semangat, sikap, nilai dan moral)".

Terdapat beberapa faktor yang dapat mempengaruhi pembentukan disiplin pada diri seseorang, antara lain adalah adanya alat pendidikan untuk mempengaruhi, mengubah, membina, dan membentuk perilaku disiplin serta diperlukan adanya teladan untuk membentuk disiplin itu sendiri. Oleh sebab itu peneliti memilih layanan penguasaan konten dengan menggunakan teknik modelling untuk membantu mengatasi permasalahan disiplin siswa. Hal ini didasarkan pada hasil penelitian yang telah dilakukan oleh Muslikah (2010: 100), hasil penelitian yang diperoleh adalah "terjadi peningkatan motivasi berprestasi

\section{METODE PENELITIAN}

Penelitian merupakan sebuah proses yang di dalamnya terdapat langkah- langkah tertentu yang harus dilakukan guna memecahkan suatu permasalahan yang telah dirumuskan sebelumnya. Metode penelitian merupakan suatu hal yang sangat penting dalam sebuah penelitian. Di dalam metode penelitian dijelaskan tentang prosedur pelaksanaan sebuah penelitian sehingga memudahkan peneliti untuk melakukan setiap langkah penelitian yang dilakukan. Sebuah hal penting yang perlu diperhatikan seorang peneliti adalah menentukan metode penelitian yang akan digunakan harus disesuaikan dengan obyek dari penelitian sehingga penelitian dapat berjalan dengan baik dan sistematis.

Dalam metode penelitian ini akan dijelaskan tentang: jenis dan desain penelitian; variabel penelitian; populasi; sampel dan teknik sampling; alat pengumpulan data; validitas dan reliabilitas; dan teknik analisis data. Jenis penelitian yang digunakan dalam penelitian ini adalah jenis penelitian eksperimental. Terdapat tiga pola yang dimasukkan ke dalam tipe pre experimental design, yaitu: one shot case study, pre test and post test, dan static group comparison. Pola yang digunakan dalam penelitian ini adalah pola pre test andpost test. Dalam pola ini observasi dilakukan sebanyak dua kali yaitu sebelum eksperimen dan sesudah eksperimen. 


\section{HASIL DAN PEMBAHASAN}

Pada bab ini akan diuraikan tentang hasil penelitian yang telah dilaksanakan dan pembahasan dari hasil penelitian. Pada sub bab hasil penelitian menjelaskan tentang gambaran kondisi kedisiplinan siswa sebelum diberi layanan penguasaan konten dengan teknik modelling simbolik (treatment), gambaran kondisi kedisiplinan siswa setelah diberi treatment, serta perbedaan kondisi kedisiplinan siswa dalam menaati tata tertib sebelum dan setelah diberi treatment. Dalam sub bab pembahasan menjelaskan secara terperinci tentang gambaran kedisiplinan siswa kelas VII A SMP Negeri 19 Kota Jambi dalam menaati tata tertib sekolah sebelum diberi treatment, gambaran kedisiplinan siswa kelas VII A SMP Negeri 19 Kota Jambi dalam menaati tata tertib sekolah setelah diberi treatment, serta perbedaan kedisiplinan siswa kelas VII A SMP Negeri 19 Kota Jambi dalam menaati tata tertib sekolah sebelum dan setelah diberi treatment.

Hasil Pengamatan pada Saat Penelitian Untuk analisis dari pengamatan yang dilakukan selama proses pelaksanaan penelitian, maka akan dipaparkan hasil pengamatan selama proses pemberian layanan penguasaan konten dari pertemuan pertama sampai pertemuan kedelapan. Pemaparan ini meliputi waktu pelaksanaan penelitian, proses pelaksanaan penelitian secara umum dan evaluasi dari setiap pertemuan.

\section{Pertemuan Pertama}

a) Waktu pelaksanaan Pertemuan pertama dilaksanakan. Kegiatan ini dilaksanakan setelah pulang sekolah. Jadwal ini ditentukan berdasarkan kesepakatan dengan para siswa setelah diadakan pre test.

b) Proses pelaksanaan. Materi yang disampaikan adalah pengenalan tentang konsep diri dengan menggunakan model tokoh yang ada di film Kungfu Panda. Sebelum pemutaran potongan film terlebih dulu peneliti melakukan apersepsi dengan siswa tentang materi yang akan disampaikan. Apersepsi yang peneliti lakukan adalah dengan menugaskan kepada siswa untuk menuliskan nama teman yang disiplin dalam hal mengerjakan tugas, menaati tata tertib dengan datang lebih awal, piket kelas, serta teman yang paling sering melanggar tata tertib. Hal ini selain bertujuan sebagai pengantar masuk ke materi juga bertujuan untuk mengetahui pemahaman siswa tentang konsep diri mereka masing-masing.

Pelaksanaan kegiatan ini terdiri dari 2 tahap yaitu pemberian model serta penyampaian materi yang berkaitan dengan model. Siswa nampak begitu antusias dalam menerima materi, beberapa siswa sempat memberikan komentarnya tentang tokoh "Po" dalam film Kungfu Panda. Dalam pemutaran model, peneliti mendampingi dan memberikan bimbingan kepada siswa tentang maksud yang terkandung dalam setiap adegan yang diputarkan.

Setelah model selesai ditayangkan peneliti menyampaikan materi tentang konsep diri dikaitkan dengan model yang telah ditayangkan. Peneliti mengajak siswa untuk mengenali konsep diri dari model yang telah ditayangkan dengan memberikan kesempatan kepada siswa untuk menyampaikan pendapatnya tentang "Po". Siswa berebut untuk bisa berbicara sehingga kelas terdengar sangat gaduh, tetapi ketika peneliti meminta mereka untuk angkat jari sebelum berbicara tidak ada siswa yang ingin maju ke depan. Akhirnya peneliti menunjuk salah satu siswa untuk maju ke depan dan mengutarakan pendapatnya. Setelah penyampaian materi peneliti memberikan tugas kepada siswa untuk menuliskan konsep diri yang mereka miliki. Kegiatan diakhiri dengan pembahasan UCA, secara umum siswa masih perlu berlatih untuk bisa menyimak dan mengambil pelajaran dari sebuah film. Siswa merasa sangat senang dengan kegiatan yang diberikan oleh peneliti, mereka berharap bisa melihat film yang berbeda. Selain itu mereka mengutarakan akan mengambil pelajaran dari setiap tayangan yang disaksikan.

c) Evaluasi kegiatan. Secara keseluruhan kegiatan berjalan dengan baik karena peneliti telah membina hubungan yang baik dengan responden sejak PPL dan rapport dibentuk lagi pada saat pelaksanaan pre test. Akan tetapi nampak seorang siswa (I) kurang serius menyaksikan potongan film "Kungfu Panda" yang diputarkan karena dia sudah pernah menyaksikan film tersebut. Siswa tersebut selalu memberikan komentar dan mengganggu teman-teman lain yang sedang menyaksikan. Peneliti memberikan arahan kepada I untuk tidak mengganggu teman-temannya yang sedang menyaksikan.

Pada pertemuan pertama ini terlihat bahwa siswa masih belum memahami tentang arti disiplin karena ketika apersepsi untuk menuliskan nama-nama teman yang disiplin siswa nampak bingung dan beberapa siswa menanyakan "Bu disiplin itu apa?". Dari sini nampak bahwa indikator pemahaman tentang peraturan yang berlaku dan manfaat yang berlaku belum terlalu dikusai. 


\section{Pertemuan Kedua}

a) Waktu Pelaksanaan. Pertemuan kedua dilaksanakan. Kegiatan ini dilaksanakan pada saat jam BK.

b) Proses Pelaksanaan. Pelaksanaan layanan ini diawali dengan pembentukan rapport, menanyakan penugasan yang telah diberikan sebelumnya kemudian meminta siswa untuk mengumpulkan tugas tersebut. Setelah itu memberikan apersepsi kepada siswa untuk menuliskan aktifitas yang dilakukan sebelum berangkat sekolah. Materi yang disampaikan pada pertemuan kedua ini adalah arti penting disiplin serta dikaitkan dengan tata tertib yang berlaku di sekolah. Pada awalnya siswa kurang antusias dengan materi yang disampaikan. Akan tetapi setelah materi selesai disampaikan kemudian diputarkan film pendek yang berjudul "Merah Putih yang Terlupakan" siswa merasa sangat tertarik. Kegiatan dilanjutkan dengan diskusi dalam kelompok, mendiskusikan tentang makna film yang telah diputarkan tersebut dikaitkan dengan materi yang telah disampaikan sebelumnya. Kemudian peneliti meminta perwakilan dari kelompok untuk membacakan hasil diskusi mereka. Dalam kegiatan ini peneliti membagi siswa dalam 4 kelompok kecil. Mereka masih saling menunjuk ketika harus maju ke depan, hanya ada satu kelompok yang tidak saling tunjuk tetapi langsung ada 1 siswa yang maju ke depan.

Kegiatan ini diakhiri dengan pembahasan UCA, siswa mulai mengerti tentang arti penting disiplin dan memahami peraturan yang berlaku di sekolah, serta mampu menceritakan dan menyimpulkan perilaku model yang ditampilkan. Mereka berkomitmen untuk tidak meniru perilaku model, karena model yang ditampilkan pada kegiatan ini berperilaku tidak disiplin.

c) Evaluasi Kegiatan. Pelaksanaan kegiatan berjalan dengan baik. Peneliti mengamati perkembangan siswa dalam 3 indikator yang menunjukkan sikap disiplin: (1) Pemahaman tentang peraturan yang berlaku. Siswa mulai mengetahui dan memahami tentang peraturan yang berlaku di sekolah. Meskipun belum semua siswa mengalami peningkatan dalam hal ini (2) Sikap mental yang baik. Siswa mulai berani untuk mengemukakan pendapatnya dengan mewakili kelompok maju ke depan. (3) Kesungguhan dalam menaati tata tertib Siswa menunjukkan sikap tanggung jawabnya dalam hal menyelesaikan tugas.

\section{Pertemuan Ketiga}

a) Waktu Pelaksanaan. Pertemuan ketiga dilaksanakan. Kegiatan ini dilaksanakan setelah pulang sekolah. Tempat pelaksanaan kegiatan di ruang kelas VII A.

b) Proses Pelaksanaan. Pelaksanaan layanan ini ada dua kegiatan yaitu penjelasan materi dan proses modelling tokoh dalam film "Laskar Pelangi" yang dilanjutkan dengan diskusi dan menelaah perilaku model yang ditampilkan. Pelaksanaan kegiatan diawali dengan pembinaan hubungan baik antara peneliti dengan siswa. Kemudian dilanjutkan dengan apersepsi yaitu dengan menanyakan pendapat siswa tentang alasan datang terlambat ke sekolah dan cara mengatasi keterlambatan tersebut. Pada saat potongan film mulai ditampilkan, siswa memperhatikan model "Lintang" dengan antusias. Setelah pemutaran potongan film selesai dilanjutkan dengan mendiskusikan karakter tokoh lintang.

Kemudian beberapa siswa diberi kesempatan untuk mengemukakan pendapatnya di depan kelas. Diantara 9 siswa yang menawarkan diri untuk maju ke depan kelas peneliti menunjuk 4 siswa sebagai perwakilan. Mereka menyimpulkan bahwa "Lintang" mempunyai karakter: mempunyai motivasi belajar tinggi, tidak mudah putus asa, sopan, pintar, percaya diri, dan disiplin serta taat pada peraturan sekolah. Siswa yang lain terlihat mendengarkan apa yang disampaikan oleh teman-teman mereka dengan baik. Peneliti memberikan reward kepada siswa yang telah maju ke depan kelas untuk bisa lebih memotivasi mereka dan siswa yang lain. Kegiatan diakhiri dengan penguatan komitmen berubah menjadi lebih baik seperti model yang ditampilkan dan pembahasan UCA. Terjadi peningkatan yang cukup baik pada pertemuan kali ini yaitu siswa dapat menganalisis tokoh dalam film dengan baik.

c) Evaluasi Kegiatan. Pelaksanaan kegiatan berjalan dengan baik. Peneliti mengamati perkembangan siswa dalam 3 indikator yang menunjukkan sikap disiplin: (1) Pemahaman tentang peraturan yang berlaku Siswa memahami bahwa peraturan sekolah dibuat untuk ditaati bukan untuk dilanggar (2) Sikap mental yang baik. Siswa mulai dapat mengendalikan diri mereka untuk tidak ribut di dalam kelas terutama pada saat pelajaran berlangsung. Meskipun masih ada beberapa siswa yang tidak memperhatikan dengan baik.

d) Kesungguhan dalam menaati tata tertib. Siswa mulai tertib pada saat pelajaran berlangsung, pada pertemuan sebelumnya siswa masih sering berpindah-pindah tempat duduk pada saat pelajaran. 


\section{Pertemuan Keempat}

a) Waktu Pelaksanaan. Pertemuan keempat dilaksanakan. Kegiatan ini dilaksanakan pada saat jam BK di ruang kelas VII A.

b) Proses Pelaksanaan. Pelaksanaan kegiatan diawali dengan pembinaan hubungan baik antara peneliti dengan siswa. Kemudian dilanjutkan dengan apersepsi yaitu dengan bertanya kepada seseorang mempunyai keinginan untuk sukses. Pada apersepsi kali ini tidak banyak siswa yang memberikan komentar mungkin dikarenakan mereka belum memahami tentang hakikat sukses. Pada pertemuan keempat peneliti menyampaikan materi menumbuhkan keinginan untuk sukses melalui cerita bergambar yang berjudul "Nita Berhasil karena Disiplin". Peneliti membagi siswa dalam 4 kelompok kecil, kemudian menugaskan mereka untuk membaca kemudian mendiskusikan isi cerita tersebut. Selama kegiatan berlangsung peneliti mendampingi siswa dan memfasilitasi siswa apabila ingin bertanya. Setelah diskusi selesai peneliti memberikan kesempatan kepada setiap perwakilan kelompok untuk menyampaikan hasil diskusi mereka di depan kelas. Mereka menyimpulkan bahwa tokoh "Nita" dapat menjadi siswa yang berhasil karena dia pandai mengatur waktu, disiplin, senang belajar, dan tidak melanggar peraturan sekolah yang telah ditetapkan. Peneliti meberikan reward kepada siswa yang telah maju ke depan. Kegiatan diakhiri pembahasan UCA, siswa memperolah pemahaman bahwa salah satu hal yang membuat seseorang berhasil adalah disiplin. Mereka menjadi lebih bersemangat dan mempunyai komitmen untuk bisa menjadi orang yang sukses.

c) Evaluasi Kegiatan Pelaksanaan kegiatan berjalan dengan baik. Peneliti mengamati perkembangan siswa dalam 3 indikator yang menunjukkan sikap disiplin: (1) Pemahaman tentang peraturan yang berlaku Siswa mulai menyadari akan mematuhi peraturan yang ditetapkan oleh sekolah. (2) Sikap mental yang baik Siswa mempunyai orientasi ke depan untuk menjadi orang yang sukses seperti tokoh "Nita".(3) Kesungguhan dalam menaati tata tertib Siswa belajar bekerjasama dengan siswa lain dalam kegiatan diskusi kelompok

\section{Pertemuan Kelima}

a) Waktu Pelaksanaan. Pertemuan kelima dilaksanakan. Kegiatan ini dilaksanakan setelah pulang sekolah dan dilaksanakan di ruang kelas VII A SMP Negeri 19 Kota Jambi.

b) Proses Pelaksanaan. Pelaksanaan kegiatan diawali dengan pembinaan hubungan baik antara peneliti dengan siswa. Kemudian dilanjutkan dengan apersepsi yaitu dengan bertanya kepada siswa tentang tata tertib yang sering dilanggar. Kegiatan ini terdiri dari 2 hal yaitu penyampaian materi tentang disiplin merupakan sebuah proses belajar dan pemutaran film "Karate Kid". Selama pemutaran film peneliti memotivasi siswa untuk memperhatikan film yang ditayangkan. Peneliti menjelaskan kepada siswa bahwa tokoh "Xiao Drew" harus latihan dari hal yang sepele dan diulang-ulang secara terus menerus untuk akhirnya bisa menang dalam turnamen karate. Kemudian peneliti memberikan kesempatan kepada siswa untuk bisa menyampaikan pendapatnya di depan kelas tentang tokoh "Xiao Drew". Perwakilan dari siswa menyampaikan bahwa mungkin awalnya Xiao Drew bosan belajar tentang hal yang sepele dan gerakan-gerakan yang sama tapi karena itu adalah aturan dan sudah ditetapkan oleh gurunya makanya dia menurut saja. Kegiatan diakhiri dengan penguatan komitmen dan pembahasan UCA. Siswa memahami bahwa belajar adalah suatu hal yang menjenuhkan tapi karena itu untuk kebaikan mereka jadi harus dilakukan dengan baik dan sungguh-sungguh.

c) Evaluasi Kegiatan. Pelaksanaan kegiatan berjalan dengan baik. Peneliti mengamati perkembangan siswa dalam 3 indikator yang menunjukkan sikap disiplin: (1) Pemahaman tentang peraturan yang berlaku. Siswa memahami bahwa setiap hari mereka harus melakukan rutinitas yang sama untuk pergi ke sekolah dan harus mematuhi peraturan yang telah ditetapkan oleh sekolah dan guru tujuannya adalah untuk kebaikan dan masa depan mereka sendiri.

d) Sikap mental yang baik. Siswa berkomitmen untuk menjadi anak yang berani dan bertanggung jawab.

e) Kesungguhan menaati tata tertib. Mereka mulai menunjukkan sikap yang baik untuk menjadi teladan bagi teman-teman yang lain. Pada pertemuan kali ini tidak ditemukan adanya siswa yang memakai pakaian tidak rapi. 


\section{Pertemuan Keenam}

a) Waktu Pelaksanaan. Pertemuan keenam dilaksanakan. Kegiatan ini dilaksanakan setelah pulang sekolah.

b) Proses Pelaksanaan. Pelaksanaan kegiatan diawali dengan pembinaan hubungan baik antara peneliti dengan siswa. Kemudian dilanjutkan dengan apersepsi yaitu dengan bertanya kepada siswa tentang manfaat tata tertib sekolah dan manfaat sikap disiplin di sekolah. Kegiatan ini terdiri dari 2 hal yaitu penyampaian materi tentang manfaat tata tertib dan manfaat sikap disiplin di sekolah. Kemudian dilanjutkan dengan pemutaran film "Kungfu Panda". Selama pemutaran film peneliti memotivasi siswa untuk memperhatikan dengan baik. Setelah film selesai diputar siswa dibagi ke dalam kelompok kecil dan mendiskusikan tayangan yang telah diputar. Hasil diskusi dibaca di depan kelas oleh salah satu anggota kelompok. Kesimpulan yang mereka ambil adalah tokoh "Po" tidak hanya mempunyai cita-cita dan tekad yang tinggi untuk bisa menjadi seorang master kungfu tetapi dia juga mempunyai kelakuan yang baik. Sekalipun teman-teman mengucilkannya tapi dia tetap berperilaku baik kepada teman-temannya. Kegiatan diakhiri dengan penguatan komitmen dan pembahasan UCA. Mereka berkomitmen untuk tidak memandang rendah teman-teman yang lain serta berusaha untuk bisa berhubungan baik dengan teman-temannya. Mereka merasa senang sekali dengan adanya pelajaran BK dan sering menonton film bersama.

c) Evaluasi Kegiatan

Pelaksanaan kegiatan berjalan dengan baik. Peneliti mengamati perkembangan siswa dalam 3 indikator yang menunjukkan sikap disiplin: (1) Pemahaman tentang peraturan yang berlaku Siswa mengetahui bahwa tata tertib yang berlaku di sekolah bermanfaat bagi mereka dan mematuhinya adalah salah satu kewajiban dan kebaikan untuk diri mereka sendiri. (2) Sikap mental yang baik. Siswa menyatakan bahwa untuk menjadi sukses seperti "Po" kita perlu berhubungan baik dengan guru dan teman-teman, dan tidak boleh saling membenci. (3) Kesungguhan dalam menaati tata tertib. Siswa bertekad untuk bisa menjadi contoh yang baik dan memanfaatkan setiap kesempatan yang ada dengan baik pula.

\section{Pertemuan Ketujuh}

a) Waktu Pelaksanaan. Pertemuan ketujuh dilaksanakan. Kegiatan ini dilaksanakan pada saat jam BK.

b) Proses Pelaksanaan. Pelaksanaan kegiatan diawali dengan pembinaan hubungan baik antara peneliti dengan siswa. Kemudian dilanjutkan dengan apersepsi yaitu dengan bertanya kepada siswa tentang citacita yang dimiliki. Mereka berebut untuk menyampaikan cita-cita yang dimiliki.

Kegiatan ini terdiri dari 2 hal yaitu penyampaian materi tentang meraih cita-cita dengan disiplin serta pemutaran slide jejak sukses mahasiswa berprestasi. Yang harus dilakukan untuk bisa mencapai cita-cita tersebut. Kemudian perwakilan siswa diminta maju ke depan untuk membacakan hasil kerja mereka. Teman-teman yang lain terlihat antusias untuk mendengarkan hasil kerja teman-temannya. Kegiatan diakhiri dengan pembahasan UCA, siswa mulai memahami bahwa memiliki cita-cita itu penting untuk lebih termotivasi dalam menjalani hidup. Dan untuk mencapai cita-cita tersebut harus selalu berusaha keras, mempunyai sikap yang positif, dan disiplin untuk menjalankan setiap aktifitas.

c) Evaluasi Kegiatan. Pelaksanaan kegiatan berjalan dengan baik. Peneliti mengamati perkembangan siswa dalam 3 indikator yang menunjukkan sikap disiplin: (1) Pemahaman tentang peraturan yang berlaku. Siswa mulai mengarahkan tindakannya sesuai dengan peraturan yang berlaku di sekolah agar tujuan mereka untuk belajar di sekolah bisa tercapai. (2) Sikap mental yang baik. Siswa menyadari bahwa untuk menjadi orang yang sukses harus mempunyai sikap yang positif serta selalu berorientasi ke depan dan berhubungan baik dengan orang-orang yang lain. (3) Kesungguhan dalam menaati tata tertib. Dalam pertemuan ketujuh nampak bahwa siswa sudah mulai menunjukkan contoh yang baik untuk temantemannya yang lain. Mereka juga memanfaatkan waktu yang diberikan untuk diskusi dengan baik.

\section{Pertemuan Kedelapan}

a) Waktu Pelaksanaan. Pertemuan kedelapan dilaksanakan. Kegiatan ini dilaksanakan setelah pulang sekolah.

b) Proses Pelaksanaan. Pelaksanaan layanan diawali dengan kuis tebak karakter tokoh sebagai apersepsi sehingga siswa tertarik dengan materi yang akan disampaikan kemudian dilanjutkan dengan menelaah perilaku model yang ditampilkan. Peneliti membagi siswa ke dalam kelompok kecil untuk memudahkan 
siswa dalam mendiskusikan rahasia kesuksesan beberapa tokoh yang ada dalam gambar. Selama kegiatan berlangsung peneliti memotivasi siswa untuk ikut aktif dalam diskusi. Beberapa siswa ada yang bertanya kepada peneliti karena mereka tidak faham dengan tokoh yang ada dalam gambar. Kemudian peneliti menjelaskan tentang tokoh yang mereka tanyakan. Salah satu perwakilan dari kelompok diminta maju ke depan untuk membacakan hasil kerja kelompok mereka. Kegiatan ini diakhiri dengan pengambilan kesimpulan dan pembahasan UCA. Kesimpulan yang dapat diambil adalah tokoh sukses dunia mencapai keberhasilannya karena mereka memiliki target dan sikap yang positif untuk mencapai target tersebut salah satunya adalah selalu berdisiplin diri.

c) Evaluasi Kegiatan. (1) Pemahaman tentang peraturan yang berlaku. Siswa menunjukkan kesadaran untuk mematuhi peraturan yang berlaku dan mengarahkan tindakannya untuk selalu berada pada norma-norma yang berlaku di sekolah. (2) Sikap mental yang baik. Siswa menunjukkan sikap berorientasi untuk menjadi orang yang sukses dan berani dalam menyampaikan pendapatnya serta dapat bekerjasama dengan teman sekelompok dengan baik. (3) Kesungguhan dalam menaati tata tertib. Siswa berkomitmen untuk bersungguh-sungguh menaati tata tertib karena peraturan sekolah dibuat untuk kebaikan dan keberhasilan mereka dalam belajar.

Berdasarkan pada tujuan dan hasil dari penelitian yang telah dilakukan, maka akan dibahas secara rinci tentang gambaran kedisiplinan siswa kelas VII A SMP Negeri 19 Kota Jambi dalam menaati tata tertib sebelum diberi layanan penguasaan konten dengan menggunakan teknik modelling, gambaran kedisiplinan siswa kelas VII A SMP Negeri 19 Kota Jambi dalam menaati tata tertib setelah diberi layanan penguasaan konten dengan menggunakan teknik modelling, dan perbedaan kedisiplinan siswa kelas VII A SMP Negeri 19 Kota Jambi dalam menaati tata tertib sebelum dan setelah diberi layanan penguasaan konten dengan menggunakan teknik modelling.

Hasil analisis deskriptif menunjukkan bahwa sebelum diberikan layanan penguasaan konten dengan menggunakan teknik modelling simbolik dari 32 siswa kelas VII A SMP Negeri 19 Kota Jambi terdapat 5 siswa $(15,63 \%)$ memiliki kategori tinggi dan 27 siswa (84,38\%) memiliki kategori sedang dalam hal kedisiplinan menaati tata tertib. Tidak ditemukan adanya siswa yang memiliki tingkat kedisiplinan dalam kategori sangat tinggi, rendah dan sangat rendah. Hasil pre test menunjukkan bahwa indikator pemahaman tentang peraturan yang baik mempunyai tingkat persentase yang paling tinggi jika dibandingkan dengan indikator yang lainnya yaitu sebesar $(68 \%)$ hal ini dikarenakan pembentukan disiplin menaati tata tertib yang ada di sekolah selama ini lebih banyak ditekankan pada hal pemahaman tentang tata tertib yang berlaku. Sedangkan indikator sikap mental yang baik mempunyai tingkat persentase yang paling rendah saat pre test yakni sebesar 65\%. Apabila ditinjau dari pendapat Bahri (2009: 27) yang menyebutkan bahwa sikap mental merupakan hasil pengembangan dan latihan pengendalian pikiran serta watak atau tingkah laku, maka dapat dikatakan bahwa hasil pemahaman seseorang tentang tata tertib akan membentuk sikap mental seseorang terhadap tata tertib pula.

Secara umum kedisiplinan siswa dalam menaati tata tertib dalam kategori sedang, atau dengan kata lain kondisi kedisiplinan siswa dalam keadaan cukup baik. Hal ini dapat terjadi karena teknik sampling yang digunakan oleh peneliti adalah probability sampling yaitu tepatnya adalah cluster random sampling. Teknik sampling ini memungkinkan setiap kelas mempunyai peluang yang sama untuk menjadi responden dalam penelitian. Oleh sebab itu kelas yang terpilih dalam teknik sampling ini memungkinkan mempunyai kriteria kedisiplinan yang berbeda dari pengamatan awal pada subyek sebelum dilaksanakan penelitian. Pada pengamatan awal sebelum dilaksanakan penelitian terlihat bahwa siswa mempunyai tingkat kedisiplinan yang rendah, tetapi hasil pre test pada responden menunjukkan tingkat kedisiplinan dengan kriteria sedang.

Hasil pre test yang menunjukkan kedisiplinan siswa berada pada kriteria sedang juga dapat diakibatkan dari instrumen penelitian yang digunakan yaitu skala kedisiplinan. Skala psikologi adalah suatu alat yang digunakan untuk mengukur atribut psikologis (Azwar, 1999: 1). Sedangkan kedisiplinan tidak hanya sekadar atribut psikologis saja tetapi perpaduan antara aspek psikologis dan juga perilaku yang nampak serta bisa diamati. Sehingga ketika siswa diminta untuk mengisikan instrumen skala kedisiplinan mereka cenderung memilih jawaban yang tampak ideal di masyarakat.

Penelitian tetap diberikan kepada responden siswa kelas VII A SMP Negeri 19 Kota Jambi meskipun hasil pre test menunjukkan secara umum siswa mempunyai kategori sedang dalam hal menaati tata tertib sekolah. Hal ini dilakukan karena salah satu fungsi utama dari layanan penguasaan konten adalah 
pemeliharaan dan pengembangan. Sesuai dengan yang diungkapkan oleh Prayitno (2004: 3) bahwa penguasaan konten dapat secara langsung maupun tidak langsung mengembangkan disatu sisi, dan disisi lain memelihara potensi individu atau klien. Apabila dikaitkan dengan penelitian ini berarti layanan penguasaan konten berfungsi untuk memelihara dan mengembangkan kondisi kedisiplinan siswa yang berada pada kriteria sedang menjadi semakin baik, terarah dan berkelanjutan.

Fungsi layanan penguasaan konten dalam penelitian ini adalah untuk membantu siswa yang telah mempunyai kriteria kedisiplinan tinggi untuk tetap mempertahankan bahkan meningkatkan kondisi tersebut. Selain itu layanan penguasaan konten dalam penelitian ini juga berfungsi untuk membantu siswa yang mempunyai kriteria sedang mengembangkan sikap disiplinnya untuk menjadi lebih baik. Oleh karena alasan tersebut penelitian ini tetap dilaksanakan dengan menggunakan responden siswa kelas VII A SMP Negeri 19 Kota Jambi.

Analisis deskriptif pada hasil post test menunjukkan adanya peningkatan pada kondisi kedisiplinan siswa dalam menaati tata tertib. Setelah diberi layanan penguasaan konten dengan menggunakan teknik modelling simbolik dari 32 siswa kelas VII A SMP Negeri 19 Kota Jambi terdapat 1 siswa $(3,13 \%)$ memiliki kategori sangat tinggi, 23 siswa $(71,87 \%)$ memiliki kategori tinggi dan 8 siswa $(25,00 \%)$ memiliki kategori sedang dalam hal kedisiplinan menaati tata tertib. Tidak ditemukan adanya siswa yang memiliki tingkat kedisiplinan dalam kategori rendah dan sangat rendah. Hal ini juga terlihat dari hasil pengamatan selama melakukan penelitian. Terjadi peningkatan pada ketiga indikator penelitian setelah siswa diberikan layanan penguasaan konten dengan menggunakan teknik modelling. Rata-rata peningkatan setiap indikator penelitian adalah $11 \%$. Indikator pemahaman tentang peraturan yang berlaku mengalami peningkatan yang paling tinggi yaitu sebesar 12\%. Hal ini diperkuat dengan pendapat dari Bahri (2009: 27) bahwa pemahaman yang baik mengenai sistem aturan tingkah laku akan menumbuhkan kesadaran untuk memahami disiplin sebagai suatu aturan yang membimbing tingkah laku. Berdasarkan pendapat tersebut dapat disimpulkan bahwa untuk membentuk sikap disiplin seseorang terlebih dulu harus memahami dan menyadari bahwa sistem aturan digunakan untuk membentuk tingkah laku.

Sedangkan indikator yang persentase peningkatannya paling rendah setelah diberikan layanan penguasaan konten dengan menggunakan teknik modelling adalah kesungguhan dalam menaati tata tertib yaitu peningkatannya sebesar $10 \%$. Yang termasuk ke dalam aspek ini adalah bertanggung jawab terhadap tugas, mengamalkan nilai-nilai yang terkandung dalam peraturan, mampu menjadi teladan, mampu bekerja sama dengan orang lain, memanfaatkan waktu dan melakukan evaluasi diri. Kesungguhan seseorang berkaitan dengan konsistensi seseorang dalam melakukan sesuatu. Sesuai dengan pendapat Hurlock (1999: 92) tujuan dari pada konsistensi adalah anak akan terlatih dan terbiasa dengan segala sesuatu yang tetap sehingga mereka akan termotivasi untuk melakukan hal yang benar dan menghindari hal yang salah. Berdasarkan pendapat tersebut dapat disimpulkan bahwa untuk menumbuhkan kesungguhan siswa dalam menaati tata tertib diperlukan adanya konsistensi baik dari segi aturan sekolah maupun dari diri siswa untuk bisa terlatih berdisiplin. Sedangkan penelitian yang dilakukan selama 8 kali pertemuan dirasa masih belum cukup untuk menumbuhkan konsistensi pada diri seseorang.

Kondisi kedisiplinan siswa sebelum diberi perlakuan berupa layanan penguasaan konten dengan menggunakan teknik modelling berada pada kriteria sedang dengan persentase $66,6 \%$. Kemudian terjadi peningkatan menjadi 77,6\% dengan kriteria tinggi, setelah diberi layanan penguasaan konten dengan teknik modelling. Dari hasil tersebut diketahui bahwa terdapat peningkatan pada kondisi kedisiplinan siswa sebesar $11 \%$. Dari hasil penelitian ini menunjukkan bahwa secara umum siswa telah memahami tentang arti dari disiplin dalam menaati tata tertib serta manfaat dari disiplin menaati tata tertib.

Selain dari perhitungan post-test, untuk dapat mengetahui bahwa keadisiplinan siswa dapat ditingkatkan melalui layanan penguasaan konten dengan teknik modelling adalah dengan melakukan analisis uji beda data penelitian pre test dan post test. Dari hasil uji beda t-test diperoleh nilai $\mathrm{t}$ hitung=10,67 dan nilai t tabel $=2,04$ dengan taraf signifikansi $5 \%$. Berdasarkan hasil uji beda tersebut diketahui bahwa nilai $t$ hitung $>\mathrm{t}$ tabel, maka Ho ditolak dengan kata lain Ha (hipotesis yang diajukan dalam penelitian) diterima. Apabila dikaitkan pada hipotesis yang ingin dibuktikan pada penelitian ini maka dapat dibuktikan bahwa kedisiplinan siswa dalam menaati tata tertib dapat ditingkatkan melalui layanan penguasaan konten dengan menggunakan teknik modelling pada siswa SMP Negeri 19 Kota Jambi. 
Dari hasil analisis uji beda t-test, perbandingan hasil pre-test dan post-test, dan pengamatan pada saat penelitian menunjukkan adanya perubahan positif pada kedisiplinan siswa kelas VII A SMP Negeri 19 Kota Jambi.

Disiplin adalah suatu sikap patuh terhadap suatu peraturan yang dilakukan secara sadar dan tanggung jawab. Disiplin merupakan salah satu kecakapan hidup yang sangat penting dan perlu dimiliki oleh setiap orang guna mencapai kesuksesan dalam hidupnya, tidak hanya kesuksesan dalam belajar tetapi juga kesuksesan dalam hidup bermasyarakat. Menanamkan disiplin pada diri diri seseorang perlu dilakukan sejak dini dan dapat dilakukan dengan berbagai cara salah satunya adalah dengan memberikan model atau contoh kepada anak. Hubungan emosional yang berkualitas serta teladan yang baik memberikan dampak positif pada kedisiplinan siswa dalam penelitian ini. Hal ini sesuai dengan pendapat dari Semiawan (2009: 95) yang menyebutkan bahwa untuk membentuk hubungan emosional yang kualitatif dan kondusif sebagai landasan untuk membentuk disiplin serta keteladanan yang berawal dari perbuatan kecil.

Dalam penelitian ini terbukti bahwa layanan penguasaan konten dengan menggunakan teknik modelling efektif untuk meningkatkan kedisiplinan siswa dalam menaati tata tertib. Hal ini sesuai dengan yang dikemukakan oleh Bandura (dalam Feist, 2008: 409) bahwa pembelajaran dengan mengamati jauh lebih efisien daripada pembelajaran dengan mengalami langsung. Dengan mengamati orang lain, manusia mempelajari respon mana yang diikuti penghukuman atau yang tidak diikuti penguatan. Pengaruh modelling ini juga diperkuat dari hasil penelitian yang telah dilakukan oleh Idad (2006) bahwa dengan memberikan contoh yang baik di lingkungan sekolah maka kedisiplinan siswa juga akan terbentuk. Berdasarkan uraian sebelumnya memperkuat hasil penelitian bahwa kondisi kedisiplinan siswa dalam menaati tata tertib dapat ditingkatkan melalui layanan penguasaan konten dengan menggunakan teknik modelling.

\section{SIMPULAN}

Berdasarkan hasil penelitian dan pembahasan, maka dapat disimpulkan sebagai berikut:

1. Kedisiplinan siswa dalam menaati tata tertib sebelum diberi layanan penguasaan konten dengan menggunakan teknik modelling pada siswa kelas VII A SMP Negeri 19 Kota Jambi tahun ajaran 2015/2016 berada pada kategori sedang.

2. Kedisiplinan siswa dalam menaati tata tertib setelah diberi layanan penguasaan konten dengan menggunakan teknik modelling pada siswa kelas VII A SMP Negeri 19 Kota Jambi tahun 2015/2016 berada pada kategori tinggi.

3. Terdapat perubahan yang positif yaitu berupa peningkatan yang signifikan pada kedisiplinan siswa dalam menaati tata tertib setelah diberi layanan penguasaan konten dengan menggunakan teknik modelling pada siswa kelas VII A SMP Negeri 19 Kota Jambi tahun 2015/2016. Hasil ini didukung dengan pengamatan terhadap responden selama penelitian.

\section{DAFTAR PUSTAKA}

Abimanyu, Soli dan Thayeb Manrihu. 1996. Tehnik dan Laboratorium Konseling. Jakarta: Direktorat Jenderal Pendidikan Tinggi.

Arikunto, Suharsimi. 1990. Manajemen Pengajaran Secara Manusiawi. Jakarta: Rineka Cipta.

Arikunto, Suharsimi. 1997. Prosedur Penelitian Suatu Pendekatan Praktek. Jakarta: Rineka Cipta.

Arikunto, Suharsimi. 2006. Prosedur Penelitian Suatu Pendekatan Praktik. Jakarta: Rineka Cipta.

Azwar, Syaifudin. 2000. Penyusunan Skala Psikologi. Yogyakarta: Pustaka Pelajar Offset.

Bahri, Syamsul. 2008. Tanggung Jawab,Disiplin, Jujur itu Keren (Pendidikan Anti Korupsi Kelas 1

SMP/MTS). Jakarta: KPK Direktorat Pendidikan dan Pelayanan Masyarakat.

Corey, Gerald. 2007. Teori dan Praktek Konseling dan Psikoterapi. Bandung: Refika Aditama.

Crain, William. 2007. Teori Perkembangan Konsep dan Aplikasi (Edisi Ketiga). Yogyakarta: Pustaka Pelajar.

Durkheim, Emile. 1990. Pendidikan Moral Suatu Studi Teori dan Aplikasi Sosiologi Pendidikan.

Jakarta: Erlangga.

Feist, Jess dan Gregory J. Feist. 2008. Theories of Personality (Edisi Keenam). Yogyakarta: Pustaka Pelajar. Hadi, Sutrisno. 2004. Statistik Jilid 2. Yogyakarta: ANDI OFFSET. 
Hamalik, Oemar. 2001. Perencanaan Pengajaran Berdasarkan Pendekatan Sistem. Bandung: Bumi Aksara. Handayani, Rinawati. 2007. Penanaman Disiplin dalam Menaati Peraturan dan Tata Tertib. Skripsi: Universitas Negeri Semarang.

Hurlock, Elizabeth B. 1999. Psikologi Perkembangan Suatu Pendekatan Sepanjang Rentang Kehidupan. Jakarta: Penerbit Erlangga.

Lemhannas. 1997. Disiplin Nasional. Jakarta: Balai Pustaka.

Margono, S. 2005. Metodologi Penelitian Pendidikan. Jakarta: PT Asdi Mahasatya.

Muryanto. 2008. Menciptakan Pribadi Anak Mudah Bergaul. Semarang: CV Ghyas Putra.

Poerwadarminto. 2003. Kamus Besar Bahasa Indonesia. Jakarta: PT Raja

Grafindo Persada.

Prayitno dan Amti, Erman. 2004. Dasar-dasar Bimbingan dan Konseling.Jakarta: Rineka Cipta.

Rimm, Sylvia. 2004. Mendidik dan Menerapkan Disiplin pada Anak Prasekolah. Jakarta: Gramedia.

Rosjidan. 1988. Pengantar Teori Konseling. Jakarta: Dirjen Dikti.

Semiawan, Conny R. 2009. Penerapan Pembelajaran Pada Anak. Jakarta: PT Ideks.

Sudjana. 1996. Metoda Statistika (edisi keenam). Bandung: Tarsito. Sugiyono. 2006. Statistika untuk Penelitian. Bandung: ALFABETA.

Sukardi, Dewa Ketut. 2003. Manajemen Bimbingan dan Konseling di Sekolah. Bandung: ALFABETA.

Tu’u, Tulus. 2004. Peran Disiplin pada Perilaku dan Prestasi Siswa. Jakarta: Grasindo.

Walgito, Bimo. 2004. Pengatar Psikologi Umum. Yogyakarta: Andi.

Wijaya, Cece dan Tabrani Rusyam. 1991. Kemampuan Dasar Guru dalam Proses Belajar Mengajar. Bandung: Remaja Rosdakarya. 